\title{
Actinomycetes of secondary metabolite producers from mangrove sediments, Central Java, Indonesia
}

\author{
Wilis Ari Setyati (D), Delianis Pringgenies (D), Nirwani Soenardjo(D) and Rini Pramesti (D) \\ Department of Marine Science, Faculty of Fisheries and Marine Science, Diponegoro University, \\ Semarang, Central Java, 50275, Indonesia. \\ Corresponding author: Wilis Ari Setyati, e-mail: wilisarisetyati@yahoo.co.id \\ Co-authors: DP: pringgenies@yahoo.com, NS: nirwanisoenardjo@gmail.com,RP: rinipramesti63@gmail.com \\ Received: 06-06-2021, Accepted: 01-09-2021, Published online: 07-10-2021
}

doi: www.doi.org/10.14202/vetworld.2021.2620-2624 How to cite this article: Setyati WA, Pringgenies D, Soenardjo N, Pramesti R (2021) Actinomycetes of secondary metabolite producers from mangrove sediments, Central Java, Indonesia, Veterinary World, 14(10): 2620-2624.

\begin{abstract}
Background and Aim: Actinomycetes are a group of Gram-positive bacteria with a fungus-like morphology. Their natural habitat encompasses terrestrial and water areas, including mangrove ecosystems. This study aimed to assess the $P K S$ and $N R P S$ genes as the producers of secondary metabolites and to determine the target bacterial species using molecular DNA tests.

Materials and Methods: In this study, we isolated bacteria from sediment samples from mangrove forests located on Karimunjawa Islands and in Semarang city, purified bacteria, screened for antibacterial activity, extracted bacterial DNA, amplified the NRPS gene, detected and amplified the PKS-I and PKS-II genes, amplified and sequenced the 16S rRNA, processed molecular data, and simulated a map of secondary metabolite producing genes.

Results: Samples from the Karimunjawa Islands yielded 19 bacterial isolates, whereas samples from Semarang yielded 11 bacterial isolates after culture in different media. Further experiments identified three active isolates, which were termed PN.SB.6.2, S.SK.6.3, and S.SK.7.1, against pathogenic species of Escherichia coli, Staphylococcus aureus, and Listeria monocytogenes. Isolate PN.SB.6.2 was determined to possess three biosynthetic gene clusters (BGCs), whereas the remaining two isolates, S.SK.6.3 and S.SK.7.1, only possessed two BGCs, namely, NRPS and PKS II.

Conclusion: Products were estimated to be in the NRPS, thiopeptide, RiPP-like, siderophore, betalactone, terpene, Type III $P K S$, CDPS, and lassopeptide groups. DNA identification of the isolates found three species of actinomycetes with antibacterial potential, namely, Virgibacillus salaries, Bacillus licheniformis, and Priestia flexa.
\end{abstract}

Keywords: actinomycetes, biosynthetic gene cluster, Karimunjawa Island, NRPS, PKS.

\section{Introduction}

Pathogenic bacteria are microbes that are capable of causing disease and can spread through the human population in a variety of ways. The solution for infectious diseases caused by pathogenic bacteria is the use of antibiotics, which are drugs that have been specially formulated to kill bacteria. Antibiotics are a group of chemical compounds that are produced organically or manufactured synthetically and can inhibit the growth of or eradicate bacteria or other organisms. Actinomycetes are a group of useful bacteria with a widespread distribution that is commonly found in terrestrial habitats $[1,2]$. They are characterized as Grampositive, filamentous, spore-forming bacteria and have $\mathrm{G}+\mathrm{C}$ content in their DNA (57-75\%). Moreover, in the past, actinomycetes were designated as an intermediate species group between bacteria and fungi, but are currently classified as prokaryotes. Most species

Copyright: Setyati, et al. Open Access. This article is distributed under the terms of the Creative Commons Attribution 4.0 International License (http://creativecommons.org/licenses/ by/4.0/), which permits unrestricted use, distribution, and reproduction in any medium, provided you give appropriate credit to the original author(s) and the source, provide a link to the Creative Commons license, and indicate if changes were made. The Creative Commons Public Domain Dedication waiver (http:// creativecommons.org/publicdomain/zero/1.0/) applies to the data made available in this article, unless otherwise stated. of actinomycetes live independently as saprophytic bacteria in soil and water, and they often associate with vascular plants $[3,4]$. Actinomycetes are members of the order Actinomycetales. This order consists of three families, namely: (1) Mycobacteriaceae: The cells of these microorganisms do not produce a mycelium or produce a rudimentary mycelium. Bacteria from Mycobacterium and Mycococcus genera fall into this category [5]; (2) Actinomycetaceae: The members of this family produce spores and are motile. The Actinomyces and Nocardia genera are among the members of this family [6]; and (3) Streptomycetaceae: The members of this family form an undivided vegetative mycelium. The Streptomyces, Micromonosora, and Thermoactinomyces genera are members of this family [7].

Actinomycetes synthesize useful antimicrobial compounds. Actinomycetes samples from the soil of various vascular plants showed antibiotic properties against the bacteria Escherichia coli and Staphylococcus aureus and the fungi Trichophyton mentagrophytes and Candida albicans [8,9]. Therefore, mangrove areas are thought to have potential as a habitat for actinomycetes. Mangrove forests are known habitat for organisms and a source of nutrition, elements, and amino acids [10-13]; 
moreover, they provide bacterial diversity [14]. The research and discovery of new types of antibiotics are extremely time-consuming and costly [15]. In an effort to discover alternative sources of antibiotics, the rediscovery of known compounds is a phenomenon that scientists encounter often. The rapid development of the genomics, bioinformatics, metabolic engineering, and synthetic biology fields provides new opportunities for the discovery of new compounds for use as antibiotics and other pharmaceutical products [16].

This study aims to detect the PKS and NRPS genes as producers of secondary metabolites from culturable actinomycetes and to determine the target bacterial species using molecular DNA tests.

\section{Materials and Methods}

\section{Ethical approval}

The study was approved by the Ethics Committee of the Faculty of Fisheries and Marine Sciences, Diponegoro University, Indonesia (4099/UN7.5.10.2/ $\mathrm{PP} / 2021)$.

\section{Study period and location}

The samples were collected from September to December 2020 in the forests of Nyamuk Island, Karimunjawa Islands, Jepara Regency, and Tapak village, Tugurejo sub-district, Semarang city. For the sake of brevity, the group samples from Nyamuk Island will be referred to as the "Karimunjawa samples" and those from the Tapak village will be referred to as "Semarang samples" hereinafter.

\section{Bacterial isolation and mangrove sediment samples}

Treatment of sediment samples up to bacterial isolation was carried out according to the method described in Davies-Bolorunduro et al. [17], with several modifications. Bacteria were isolated using the spread plate method with stratified dilution. From each dilution, $50 \mu \mathrm{L}$ was taken and was spread on the surface of five different types of media. The media used were marine agar (Zobell), International Streptomyces Project 1 (ISP 1), humic acid vitamin agar (HVA) [18], and two modified media, that is, the ISP $11+$ humic acid (HA) and marine agar + HA (Zobell + HA). Nystatin $(60 \mathrm{mg} / \mathrm{L})$ was introduced into each medium, and all media were incubated at $29-34^{\circ} \mathrm{C}$ for $1-7$ days.

\section{Purification of bacteria and screening of antibacte- rial activity}

The bacterial isolates were purified according to Davies-Bolorunduro et al. [17]. The Actinomycetes that developed on the isolation media were grouped according to their morphology. Each isolate was grown on new media using the streak plate method followed by reincubation at $29-34^{\circ} \mathrm{C}$ for $1-5$ weeks. The bacterial screening described here refers to the Kirby-Bauer method, with several modifications [19]. Two-week-old bacteria cultured on the disks were then placed onto the surface of Mueller-Hinton agar plates impregnated with the test pathogenic bacteria ( $S$. aureus,
E. coli, Listeria monocytogenes, and Enterobacter aerogenes).

\section{Bacterial DNA extraction}

The Chelex method was employed for DNA extraction [20]. Fifty microliters of Aqua Bidest and $1 \mathrm{~mL}$ of $0.5 \%$ saponin were added to PBS. This mixture was incubated overnight at $4^{\circ} \mathrm{C}$. After incubation, the mixture was homogenized using a centrifuge at a speed of $12,000 \mathrm{rpm}$ for $10 \mathrm{~min}$. The resulting supernatant was then removed and $1 \mathrm{~mL}$ of PBS was added to the mixture before reintroduction into the centrifuge. The resulting supernatant was discarded to remove saponin. Subsequently, another $100 \mu \mathrm{L}$ of Aqua Bidest and $50 \mu \mathrm{L}$ of Chelex $20 \%$ were added to the mixture, which was then heated for $10 \mathrm{~min}$ and placed in a vortex machine for $5 \mathrm{~min}$. The preparation was then processed in a centrifuge at $12,000 \mathrm{rpm}$ for $10 \mathrm{~min}$. The extract was kept in a freezer for $24 \mathrm{~h}$ for the determination of DNA quality using a nanodrop device.

\section{NRPS gene amplification and PKS-I and PKS-II gene detection and amplification}

$N P R S$ gene detection was performed using a PCR method with a primer pair consisting of A2gam F (5'-AAGGCNGGCGSBGCSTAYSTGCC-3') and A3gamR (5'-TTGGGBIK BCCGGTSGINCCSG AGGTG-3') [21]. PKS-I and PKS-II gene detection and amplification were carried out according to the method described in El Samak et al. [22].

\section{S rRNA amplification and sequencing}

The DNA amplification performed in this study was a replication of the method reported in Radjasa et al. [23]. The primers used were as follows: Forward: 5'-AGAGTTTGATCMTGGCTCAG-3', positions 8-27 and 1500; reverse: 5'-GGTTACCTTGTTACGACTT-3', positions 1510-1492 based on the sequence of the $16 \mathrm{~S}$ rRNA from E. coli [24]. The PCR DNA amplification method was carried out on a thermal cycler (Mini cycler TM, MJ Research Inc., Watertown, MA, USA) with the following temperature conditions: Initial denaturation at $94^{\circ} \mathrm{C}$ for $2 \mathrm{~min}$; followed by 30 cycles of denaturation at $94^{\circ} \mathrm{C}$ for $2 \mathrm{~min}$, annealing at $45^{\circ} \mathrm{C}$ for $2 \mathrm{~min}$, and extension at $72^{\circ} \mathrm{C}$ for $2 \mathrm{~min}$; and a final extension at $72^{\circ} \mathrm{C}$ or $3 \mathrm{~min}$. Electrophoresis was carried out by inserting $1 \mu \mathrm{L}$ of the PCR product aliquot into a well that was filled with $1 \%$ agarose gel. The preparations were then placed in $50 \times$ TAE buffer and observed to determine whether the DNA amplification was satisfactory. The products of PCR amplification were purified and concentrated using a Microcon-100 microconcentrator (Amicon, Beverly, MA, USA) according to the OEM manual. Finally, $16 S$ rDNA gene sequences were determined using the SequiTherm Long-Read Sequencing Kit (Epicenter Technologies, Madison, WI, USA).

\section{Molecular data processing and genetic mapping sim-} ulation of secondary metabolite producers

The data obtained from sequencing were edited using the MEGA 7.0 software. The data from the 
Table-1: Antibacterial activity screening of Karimunjawa and Semarang isolates.

\begin{tabular}{llccc}
\hline Isolate code & Origin & \multicolumn{2}{c}{ Inhibition zone against pathogenic bacteria (cm) } \\
\cline { 3 - 5 } & & Escherichia coli & Staphylococcus aureus & Listeria monocytogenes \\
\hline PN.SB.6.2 & Karimunjawa & - & - & $1.69 \pm 0.36$ \\
S.SK.6.3 & Semarang & $0.84 \pm 0$ & $0.60 \pm 0.08$ & $1.17 \pm 0.58$ \\
S.SK.7.1 & Semarang & - & $0.90 \pm 0.07$ & - \\
\hline
\end{tabular}

16s $r D N A$ sequencing were then matched with data from the NCBI GenBank. Whole-genome sequencing data from the same species as that of the candidate obtained based on molecular identification were downloaded from GenBank. The data were then submitted to AntiSMASH, to obtain an approximate map of the genes that produce secondary metabolites.

\section{Results}

\section{Bacterial isolation and antibacterial activity}

The isolation of actinomycetes from samples resulted in 19 isolates from the Karimunjawa Islands and 11 isolates from Semarang. Bacterial isolation from the mangrove sediments collected in Semarang and the Karimunjawa Islands was performed using four types of media. Together, these media yielded 30 isolates. The ISP 1 medium yielded in nine Semarang and six Karimunjawa isolates. The ISP1 + HA gave one Semarang isolate and two Karimunjawa isolates, whereas the Zobell + HA only yielded nine Karimunjawa isolates. The Zobell medium gave the greatest number of isolates; however, all of them exhibited low biodiversity. In contrast, only specific bacteria from the soil were able to grow on selective media (media containing HA). This is because HA is an important component of soil, as presented in Figure-1.

Screening for antibacterial activity against several pathogenic species, that is, S. aureus, E. coli, and L. monocytogenes, identified three isolates that actively produced antibiotic compounds, as presented in Table-1. Three bacterial isolates from mangrove sediment samples exhibited antibacterial properties. The Karimunjawa isolate that was able to inhibit the growth of pathogenic bacteria was isolate number PN.SB.6.2, with activity against L. monocytogenes. The Semarang isolate that afforded antibiotic susceptibility toward the pathogenic species included in this study was isolate S.SK.6.3, with activity against $E$. coli (Gram-negative bacterium), S. aureus (Gram-positive bacterium), and L. monocytogenes (Gram-positive bacterium). Another Semarang isolate, S.SK.7.1, exhibited antibacterial activity against $S$. aureus. The results of this screening also revealed that S.SK.6.3 is a bacterial isolate with wide spectrum antibacterial properties.

Biosynthetic gene cluster (BCG) detection and $16 S$ rRNA-based molecular identification of active isolates

BCGs screening, including the NRPS, type I $P K S$, and type II $P K S$ genes, of the Karimunjawa
Table-2: BGC screening.

\begin{tabular}{lccc}
\hline Isolate code & \multicolumn{2}{c}{$\begin{array}{c}\text { Coding genes for secondary } \\
\text { metabolites }\end{array}$} \\
\cline { 2 - 4 } & NRPS gene & PKS I gene & PKS II gene \\
\hline PN.SB.6.2 & $\checkmark$ & $\checkmark$ & $\checkmark$ \\
S.SK.6.3 & $\checkmark$ & $\checkmark$ & $\checkmark$ \\
S.SK.7.1 & $\checkmark$ & $\checkmark$ & $\checkmark$ \\
\hline
\end{tabular}

BGC=Biosynthetic gene cluster

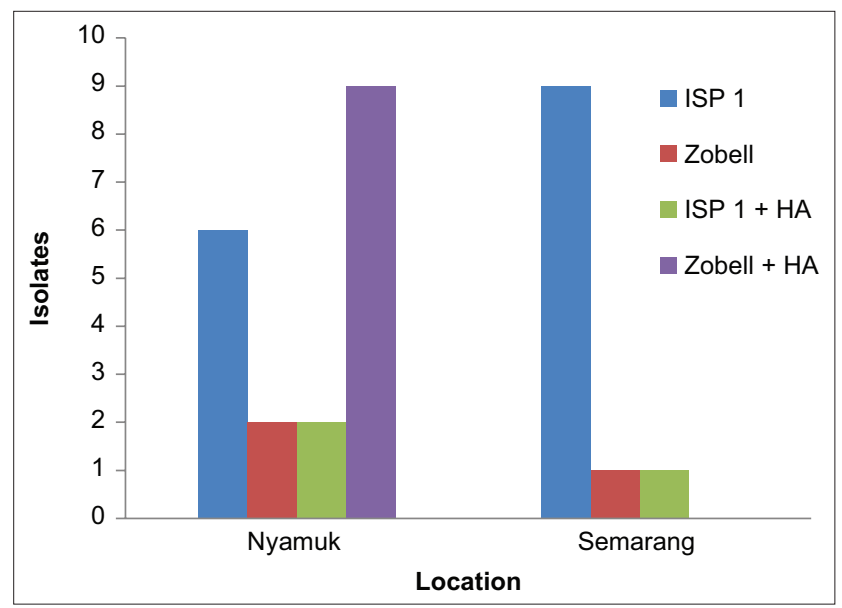

Figure-1: The number of isolates successfully obtained from Karimunjawa and Semarang based on culture media.

Islands and Semarang isolates resulted in the data that are presented in Table-2. Isolate PN.SB.6.2 was determined to possess three BGCs, whereas the remaining two isolates, S.SK.6.3 and S.SK.7.1, only possessed the NRPS and PKS II genes.

The 16S rRNA-based molecular identification data from the Karimunjawa and Semarang isolates are presented in Table-2. The active bacterial isolate coded as PN.SB.6.2 was identified as Virgibacillus salarius, with $100 \%$ matching to the data access number LC537902.1. In turn, the bacterial isolate coded as S.SK.6.3 was identified as Priestia flexa, with 100\% compatibility to the data access number MT279468.1. Finally, the bacterial isolate coded as S.SK.7.1 was identified as Bacillus licheniformis, with 100\% compatibility to the data access number MT642946.1 (Table-3).

\section{BGC mapping simulation using AntiSMASH 6.0}

Mapping simulation of BGCs using AntiSMASH 6.0 in the whole genome of the species that matched P. flexa (S.SK.6.3) provided six regions producing secondary metabolites (Table-4). Estimates of the resulting products include lassopeptide, terpene, siderophore, NRPS, and Type III PKS groups. 
Table-3: Molecular identification of Semarang and Karimunjawa isolates.

\begin{tabular}{llccc}
\hline $\begin{array}{l}\text { Isolate } \\
\text { code }\end{array}$ & $\begin{array}{l}\text { Species identification } \\
\text { (BLAST) }\end{array}$ & $\begin{array}{c}\text { Accession } \\
\text { no. }\end{array}$ & $\begin{array}{c}\text { Sequence length } \\
\text { (bp) }\end{array}$ & $\begin{array}{c}\text { Identity } \\
\text { (\%) }\end{array}$ \\
\hline PN.SB.6.2 & Virgibacillus salarius & MW990225 & 480 & $100 \%$ \\
S.SK.6.3 & Priestia flexa & MW990226 & 1402 & $100 \%$ \\
S.SK.7.1 & Bacillus licheniformis & MW990227 & 787 & $100 \%$ \\
\hline
\end{tabular}

Table-4: Bacillus flexus/Priestia flexa (NZ_FMBD01000005.1).

\begin{tabular}{lccc}
\hline Region & Region Iocation (nucleotides) & Type & $\begin{array}{c}\text { Most similar } \\
\text { known cluster }\end{array}$ \\
\hline Region 5.1 & $12,591-36,521$ & Lassopeptide & Paeninodin \\
Region 5.2 & $41,198-63,054$ & Terpene & - \\
Region 6.1 & $37,947-53,928$ & Siderophore & - \\
Region 11.1 & $1-39,588$ & NRPS & Bacillibactin \\
Region 24.1 & $1-28,758$ & Type III PKS & - \\
Region 52.1 & $1-23,842$ & NRPS & - \\
\hline
\end{tabular}

\section{Discussion}

$V$. salarius is a member of the Virgibacillus genus and is a Gram-positive bacterium [25]. The species is known to produce compounds with antibacterial properties [26,27]. P. flexa, previously known as Bacillus flexus, is a Gram-positive bacterium from the genus Priestia. The previous studies reported that this species also shows antibacterial properties against other pathogenic species [28]. B. licheniformis is a species that is found abundantly in soil. This bacterium is prized in the industrial sector for its ability to produce the alkaline enzyme serine protease [29]. In addition, the species has also been reported to possess antibiotic activity with a large spectrum [30]. The data obtained from the 16S rRNA sequencing of the three samples have been deposited in GenBank, with access numbers MW990225, MW990226, and MW990227.

Region 11.1 had 53\% match with the gene clusters of organisms that produce $\mathrm{Fe}$ ion-binding compound (bacillibactin) [31]. Several other regions have not been determined to have any matches with specific secondary metabolite producing genes. Mapping simulation of BGCs in the whole genome of the same species with $B$. licheniformis (S.SK.7.1) samples identified 10 regions of secondary metabolite producing gene clusters. The resulting products were estimated to be in the NRPS, thiopeptide, RiPP-like, siderophore, betalactone, terpene, Type III PKS, CDPS, and lassopeptide groups. Two gene clusters were determined to have similarities with the antibiotic-producing gene clusters.

Among all of these secondary metabolite-producing regions, gene clusters were identified that were similar to the antibiotic-producing gene clusters, Region 5.1, which exhibited an $80 \%$ match with the paeninodin producing gene clusters [32], as shown in Table-4. Region 2 exhibited a $7 \%$ match with gene clusters producing butirosin $\mathrm{A} / \mathrm{B}$ [33] and lichenicidin VK21 A1 [34], as shown in Table-4.

\section{Conclusion}

Thirty isolates of actinomycetes were identified in this study; 19 of them were from the Karimunjawa sample and 11 of them were from the Semarang sample, after culture on different media. Among the isolates identified here, three showed antibacterial activity against the E. coli (Gram-negative bacterium), $S$. aureus (Gram-positive bacterium), and L. monocytogenes (Gram-positive bacterium) pathogenic species. Isolate PN.SB.6.2 possessed three BGCs, whereas the remaining two isolates, S.SK.6.3 and S.SK.7.1, only possessed two BGCs, namely, NRPS and PKS II. DNA identification of the isolates yielded three species of actinomycetes with antibacterial potential, namely, Virgibacillus salaries, B. licheniformis, and P. flexa.

\section{Authors' Contributions}

WAS and DP: Designed the study. NS: Prepared the samples. WAS, DP, and RP: Performed data collection, statistical analysis, data interpretation, and manuscript writing. WAS and DP: Supervised the study and manuscript editing. All authors read and approved the final manuscript.

\section{Acknowledgments}

This study was partly and financially supported by the grant from the Faculty of Fisheries and Marine Sciences, Diponegoro University, Indonesia (contract no. 80/UN7.5.10.2/PP/2021). The authors would like to express gratitude to the Dean of the Faculty of Fisheries and Marine Sciences, Diponegoro University, Indonesia, for providing necessary facilities for the study.

\section{Competing Interests}

The authors declare that they have no competing interests.

\section{Publisher's Note}

Veterinary World remains neutral with regard to jurisdictional claims in published institutional affiliation. 


\section{References}

1. Kumar, V., Bisht, G.S. and Gusain, O. (2013) Terrestrial actinomycetes from diverse locations of Uttarakhand, India : Isolation and screening for their antibacterial activity. Iran. J. Microbiol., 5(3): 299-308.

2. Trenozhnikova, L. and Azizan, A. (2018) Discovery of actinomycetes from extreme environments with potential to produce novel antibiotics. Cent. Asian J. Glob. Health., 7(1): 337.

3. Shimizu, M. (2011) Bacteria in Agrobiology: Plant Growth Responses. Springer, United States. p201-220.

4. Barka, E.A., Vatsa, P., Sanchez, L., Nathalie GaveauVaillant, C.J., Klenk, H.P., Clément, C., Ouhdouch, Y. and van Wezeld, G.P. (2016) Taxonomy, physiology, and natural products of actinobacteria. $A S M, 80(1): 1-43$.

5. Lory, S. (2014) The prokaryotes: Actinobacteria. Springer, United States. p1-1061.

6. Yassin, A.A.F. (2014) The Prokaryotes: Actinobacteria. Springer, United States.

7. Kämpfer, P. (2006) The Family Streptomycetaceae, Part I: Taxonomy. in the Prokaryotes. Springer, United States.

8. Sarker, A.K., Haque, M.A., Islam, M.S., Rahman, M.A. and Islam, M.A.U. (2015) Antibacterial activities of actinomycete isolates collected from soils of Rajshahi, Bangladesh. Biotechnol. Res. Int., 18(1): 1-6.

9. Elbendary, A.A., Hessain, A.M., El-Hariri, M.D., Seida, A.A., Moussa, I.M., Mubarak, A.S., Kabli, S.A., Hemeg, H.A. and El Jakee, J.K. (2018) Isolation of antimicrobial producing actinobacteria from soil samples. Saudi $J$. Biol. Sci., 25(1): 44-46.

10. Ariyanto, D., Bengen, D.G., Prartono, T. and Wardiatno, Y. (2020) Distribution and abundance of Cerithideopsilla djadjariensis (Martin 1899) (potamididae) on Avicennia marina in Rembang, Central Java, Indonesia. Egypt. J. Aquat. Biol. Fish., 24(3): 323-332.

11. Ariyanto, D. (2019) Food preference on Telescopium telescopium (Mollusca: Gastropoda) based on food sources in mangrove. Plant Arch., 19(1): 913-916.

12. Ariyanto, D., Gunawan, H., Puspitasari, D., Ningsih, S.S., Jayanegara, A. and Hamim, H. (2019) The differences of the elements content in Rhizophora mucronata leaves from Asahan Regency, North Sumatra, Indonesia. Pol. J. Nat. Sci., 34(4): 481-491.

13. Ningsih, S.S., Ariyanto, D., Puspitasari, D., Jayanegara, A., Hamim, H. and Gunawan, H. (2020) The amino acid contents in mangrove Rhizophora mucronata leaves in Asahan, North Sumatra, Indonesia. E3S Web Conf., 151(01047): 1-3.

14. Basak, P., Pramanik, A., Sengupta, S., Nag, S., Bhattacharyya, A., Roy, D., Pattanayak, R., Ghosh, A., Chattopadhyay, D. and Bhattacharyya, M. (2016) Bacterial diversity assessment of pristine mangrove microbial community from Dhulibhashani, Sundarbans using $16 S \mathrm{rRNA}$ gene tag sequencing. Genom. Data., 7: 76-78.

15. Sharma, P. and Thakur, D. (2020) Antimicrobial biosynthetic potential and diversity of culturable soil actinobacteria from forest ecosystems of Northeast India. Sci. Rep., 10(1): 1-18.

16. Sekurova, O.N., Schneider, O. and Zotchev, S.B. (2019) Novel bioactive natural products from bacteria via bioprospecting, genome mining, and metabolic engineering. Microb. Biotechnol., 12(5): 828-844.

17. Davies-Bolorunduro, O.F., Adeleye, I.A., Akinleye, M.O. and Wang, P.G. (2019) Anticancer potential of metabolic compounds from marine actinomycetes isolated from Lagos Lagoon sediment. J. Pharm. Anal., 9(3): 201-208.

18. Hayakawa, M. and Nonomura, H. (1987) Humic acid-vitamin agar, a new medium for the selective isolation of soil actinomycetes. J. Ferment. Technol., 65(5): 501-509.

19. Hudzicki, J. (2009) Kirby-Bauer disk diffusion susceptibility test protocol. American Society for Microbiology, United States. p1-23.

20. Walsh, P.S., Metzger, D.A. and Higuchi, R. (2013) Biotechniques $30^{\text {th }}$ anniversary gem Chelex 100 as a medium for simple extraction of DNA for PCR-based typing from forensic material. BioTechniques., 54(3): 506-513.

21. Radjasa, O.K., Martens, T., Grossart, H.P., Sabdono, A., Simon, M. and Bachtiar, T. (2005) Antibacterial property of a coral-associated bacterium Pseudoalteromonas luteoviolacea against shrimp pathogenic Vibrio harveyi (in vitro study). HAYATI J. Biosci., 12(2): 77-81.

22. El Samak, M., Solyman, S.M. and Hanora, A. (2018) Antimicrobial activity of bacteria isolated from Red Sea marine invertebrates. Biotechnol. Rep., 19: e00275.

23. Radjasa, O.K., Urakawa, H., Kita-Tsukamoto, K. and Ohwada, K. (2001) Characterization of psychrotrophic bacteria in the surface and deep-sea waters from the northwestern Pacific Ocean based on 16S ribosomal DNA analysis. Mar. Biotechnol., 3(5): 454-462.

24. Weisburg, W.G., Barns, S.M., Pelletier, D.A. and Lane, D.J. (1991) 16S ribosomal DNA amplification for phylogenetic study. J. Bacteriol. Res., 173(2): 697-703.

25. Hua, N.P., Hamza-Chaffai, A., Vreeland, R.H., Isoda, H. and Naganuma, T. (2008) Virgibacillus salarius sp. nov., a halophilic bacterium isolated from a Saharan salt lake. Int. J. Syst. Evol., 58(10): 2409-2414.

26. Kristiana, R., Ayuningrum, D., Asagabaldan, M.A., Nuryadi, H., Sabdono, A., Radjasa, O.K. and Trianto, A. (2016) Isolation and partial characterization of bacteria activity associated with Gorgonian Euplexaura sp. Against methicillin-resistant Staphylococcus aureus (MRSA). J. Phys. Conf. Ser., 55: 1-6.

27. Ayuningrum, D., Muchlissin, S.I., Trianto, A., Radjasa, O.K. and Sabdono, A. (2020) Crude extract from a hardcoral-associated bacterium Virgibacillus salarius PHC-44-04 inhibiting growth of Multidrug-Resistant Enterobacter aerogenes human pathogen. J. Asian Nat. Prod. Res., 18(2): 78-83.

28. Wijayanti, D.P., Sabdono, A., Dirgantara, D., Widyananto, P.A., Sibero, M.T., Bhagooli, R. and Hidaka, M. (2020) Antibacterial activity of acroporid bacterial symbionts against white patch disease in Karimunjawa Archipelago, Indonesia. Egypt. J. Aquat. Res., 46(2): 187-193.

29. Schallmey, M., Singh, A. and Ward, O.P. (2004) Developments in the use of Bacillus species for industrial production. Can. J. Microbiol., 50(1): 1-17.

30. Shobharani, P., Padmaja, R.J. and Halami, P.M. (2015) Diversity in the antibacterial potential of probiotic cultures Bacillus licheniformis MCC2514 and Bacillus licheniformis MCC2512. Res. Microbiol., 166(6): 546-554.

31. Zhou, M., Liu, F., Yang, X., Jin, J., Dong, X., Zeng, K.W., Liu, D., Zhang, Y., Ma, M. and Yang, D. (2018) Bacillibactin and bacillomycin analogues with cytotoxicities against human cancer cell lines from marine Bacillus sp. PKU-MA00093 and PKU-MA00092. Mar. Drugs., 16(22): 1-14.

32. Zhu, S., Hegemann, J.D., Fage, C.D., Zimmermann, M., Xie, X., Linne, U. and Marahiel, M.A. (2016) Insights into the unique phosphorylation of the lasso peptide paeninodin. J. Biol. Chem., 291(26): 13662-13678.

33. Llewellyn, N.M., Li, Y. and Spencer, J.B. (2007. Biosynthesis of butirosin: Transfer and deprotection of the unique amino acid side Chain. Chem. Biol., 14(4): 379-386.

34. Shenkarev, Z.O., Finkina, E.I., Nurmukhamedova, E.K., Balandin, S.V., Mineev, K.S., Nadezhdin, K.D., Yakimenko, Z.A., Tagaev, A.A., Temirov, Y.V., Arseniev, A.S. and Ovchinnikova, T.V. (2010) Isolation, structure elucidation, and synergistic antibacterial activity of a novel two-component lantibiotic lichenicidin from Bacillus licheniformis VK21. Biochemistry., 49(30): 6462-6472. 